\title{
Kesiapan Kota Surakarta dalam MewUJUdKan \\ Pariwisata CERdas (SMart Tourism) Ditinjau dari ASPEK Fasilitas dan Sistem Pelayanan
}

\author{
AZRINA FARANIA ${ }^{1}$ \\ Program STUdi PERENCANAAN WILAYAH DAN KoTA \\ FAKULTAS TEKNIK \\ UNIVERSITAS SEBELAS MARET, SURAKARTA \\ email: azrin.farania@gmail.com \\ ANA HARDIANA ${ }^{2}$ \\ PROGRAM STUDI PERENCANAAN WILAYAH DAN KOTA \\ FAKULTAS TEKNIK \\ PUSAT INFORMASI DAN PEMBANGUNAN WILAYAH (PIPW), LPPM \\ UNIVERSITAS SEBELAS MARET, SURAKARTA \\ RUFIA ANDISETYANA PUTRI ${ }^{3}$ \\ PROGRAM STUDi PERENCANAAN WILAYAH DAN KoTA \\ FAKULTAS TEKNIK \\ PUSAT INFORMASI DAN PEMBANGUNAN WILAYAH (PIPW), LPPM \\ UNIVERSITAS SEBELAS MARET, SURAKARTA
}

\begin{abstract}
The increasing of urban development responds to various problems that occur. The existence of the city's problems requires cities and communities in it to solve the problem, coupled with global challenges related to how the city is able to compete both national and international scale. Progress in the development of city manifested through innovations in the life of the city which is then often referred to as Smart City. The concept of Smart City is also needed in the tourism aspect or commonly called Smart Tourism. The development of tourism continues to grow and has been synergized with Information and Communication Technology (ICT) including in Surakarta City that trying to apply the concept of Smart Tourism, such as the launch of Solo Destination application and the cooperation of government and Telecommunication Company to realize smart tourism. But its application is still not perfect yet, especially if viewed from facility and service system. This is seen in the availability of Information and Communication Technology in support of tourism activities are minimal. The problem is also seen in the inadequate service quality in all components of tourism. This paper determine the readiness of Surakarta City in realizing the tourism smart in terms of facilities and service system based on four components (1) tourism actors, (2) attractions, (3) transportation and (4) tourism supporting facilities. The approach is using deductive, while the analysis method is quantitative using the scoring analysis from the results of field observation and data review. The result shown that the city of Surakarta is ready in applying the concept of smart tourism, although the attraction component is less ready that cause the attraction has not been able to play a major component of tourism that is able to attract many tourist visitors. Other components such as tourism actors, transportation and tourism supporting facilities already indicate ready.
\end{abstract}

Keywords: facility and service system, readiness, smart city, smart tourism

\section{PENDAHULUAN}

Pertambahan jumlah penduduk dan semakin meningkatnya kegiatan pembangunan kota pada berbagai sektor berdampak pada kemajuan yang pesat dalam perkembangan kota
[Rustanto, 2007]. Kompleksitas permasalahan kota menuntut kota dan masyarakat untuk menyelesaikan masalah tersebut secara inovatif, efektif, efisien dan mengoptimalkan sumberdaya yang ada. Oleh karena itu, adanya tantangan global bagi kota 
untuk mampu bersaing di skala nasional maupun internasional, mendorong kota dan masyarakat untuk berinovasi dalam memajukan kota. Inovasi-inovasi yang tercipta untuk menyelesaikan permasalahan kota berdampak positif pada kemajuan pembangunan kota di berbagai bidang. Kota-kota yang menawarkan pelayanan yang maju dan inovatif bagi masyarakatnya ini sering disebut sebagai kota cerdas (Smart City) [Piro, et. al, 2014]. Konsep kota cerdas tersebut juga dapat diaplikasikan pada bidang pariwisata yang biasa disebut Pariwisata Cerdas (Smart Tourism) [Liu dan Liu, 2016].

Sistem pariwisata cedas meliputi lima elemen: Information Exchange Center (IEC), government/pemerintah, scenic zone/zona indah dan bisnis [Zhui et.al, 2014]. Pengaplikasian dalam bidang pariwisata ini dibutuhkan karena adanya perkembangan kegiatan berwisata yang telah menjadi kebutuhan hidup masyarakat. Sejak tahun 2010 jumlah kedatangan wisatawan internasional mengalami pertumbuhan rata-rata $5 \%$ setiap tahunnya. Tren ini mengindikasikan adanya pertumbuhan ekonomi yang meningkat, ditunjukkan oleh meningkatnya aktivitas ekspor dan luasnya lapangan pekerjaan di bidang pariwisata [UNWTO, 2014].

Sebagai salah satu kota cerdas di Indonesia, Kota Surakarta juga mencoba menerapkan konsep tersebut dalam bidang pariwisata melalui konsep Smart Tourism (Pariwisata Cerdas). Dalam menerapkan konsep kota cerdas, Pemerintah Kota Surakarta telah berkerjasama dengan Indosat bersama PT. StarOne Mitra Telekomunikasi (SMT) melalui kolaborasi yang mendukung E-government, E-tax, Etransportation, Smart tourism, Workforce Management dan Smart Street Lighting [Indosatooredo.com, 2015]. Pelaksanaan konsep Smart Tourism tersebut terwujud dengan pengimplementasian salah satu elemen yaitu IEC seperti aplikasi mobile Solo Destination yang telah diluncurkan oleh pemerintah Kota Surakarta melalui Dinas Perhubungan, Komunikasi dan Informatika (Dishubkominfo). Sejak diluncurkannya aplikasi Solo Destination pada tahun 2014 hingga saat ini, aplikasi ini telah mencapai 10.000 pengunggah. $\mathrm{Hal}$ ini mengindikasikan cukup banyaknya masyarakat yang menginginkan sebuah platform informasi dan pelayanan yang mudah dan efektif khususnya terkait dengan pariwisata.

Meskipun konsep pariwisata cerdas ini telah diterapkan di Kota Surakarta namun dalam penerapannya masih belum sempurna, terutama jika ditinjau dari fasilitas dan sistem pelayanannya. Hal ini terlihat pada minimnya ketersediaan Tekonologi Infomasi dan Komunikasi (TIK) dalam menunjang kegiatan pariwisata. Beberapa objek wisata belum memanfaatkan software komputer dalam operasionalisasinya seperti Wayang Orang Sriwedari dan Keraton Kasunanan. Permasalahan juga terlihat pada belum optimalnya kualitas pelayanan dalam semua elemen pariwisata. Beberapa objek wisata belum terjangkau trayek transportasi umum dan belum terlayani semua jenis fasilitas penunjang wisata sehingga kebutuhan wisatawan belum terpenuhi secara optimal. Hal ini mengindikasikan bahwa secara umum penerapan pariwisata cerdas (smart tourism) pada Kota Surakarta masih belum sempurna dan tidak terlepas dari berbagai masalah.

Artikel ini bertujuan untuk mengetahui kesiapan Kota Surakarta dalam mewujudkan Pariwisata Cerdas jika ditinjau dari fasilitas dan sistem pelayananya. Sasaran yang dilakukan untuk mencapai tujuan meliputi teridentifikasinya karakteristik komponen pariwisata cerdas ditinjau dari fasilitas dan sistem pelayanan dan 
terumuskannya tingkat kesiapan pariwisata cerdas di Kota Surakarta ditinjau dari fasilitas dan sistem pelayanan. Ruang lingkup waktu data yang digunakan adalah tahun terakhir (2017). Cakupan wilayah pembahasan adalah atraksi wisata yang berupa objek wisata berjumlah 9, meliputi Taman Satwa Taru Jurug, Kawasan Keraton
Kasunanan, Kawasan Keraton Mangkunegaran, Wayang Orang Sriwedari, THR Sriwedari, Kampung Batik Kauman, Kampung Batik Laweyan, Taman Balekambang, dan Museum Radya Pustaka [RIPKD Kota Surakarta 2016-2026 dan Peneliti, 2017].

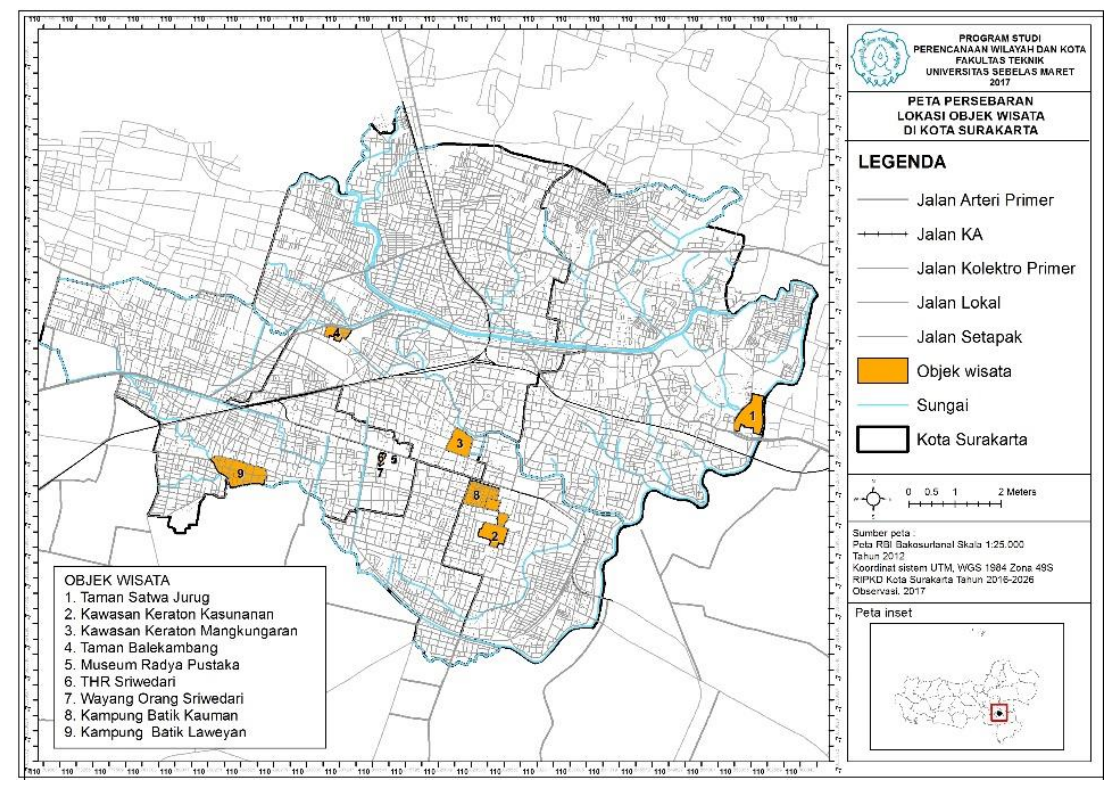

Gambar 1. Ruang Lingkup Wilayah Sumber: RIPKD Kota Surakarta 2016-2026, Peneliti, 2017.

\section{TINJAUAN PUSTAKA}

Pengukuran kesiapan sebuah kota digunakan untuk mengukur seberapa keadaan siap/matang suatu kota. Kesiapan didasarkan pada ketelitian dalam perencanaan, kecukupan dan pelatihan pelaku, serta tersedianya pasokan dan cadangan layanan pendukung atau sistem [businessdictionary.com].

Pasokan dan cadangan layanan pendukung atau sistem ini merujuk pada fasilitas dan sistem pelayanan yang ada dalam kota. Pelayanan yang dimaksud adalah setiap kegiatan yang dapat diberikan oleh suatu pihak kepada pihak lainnya dalam interaksi langsung antar sesorang dengan orang lain atau mesin secara fisik dengan tujuan untuk kepuasan pelanggan [Sinambela, 2007]. Fasilitas dan sistem pelayanan yang merupakan sistem kegiatan untuk melayani masyarakat merupakan aspek paling penting dibanding aspek kesiapan lainnya. Jika tidak ada fasilitas atau sistem pelayanan maka tidak ada kegiatan yang diimplementasikan dari rencana dan tidak ada pula objek yang dioperasionalkan oleh pelaku.

Menurut Piu Liu dan Yuan Liu [2016], pariwisata cerdas (smart tourism) erat kaitannya dengan kota cerdas (smart city), karena pariwisata cerdas muncul dari konsep kota cerdas yang bergantung pada infrastruktur dan penguatan keterkaitan setiap subsistem pada kota cerdas serta keterkaitan antar sistem kota cerdas 
sehingga mampu memperkaya konsep kota cerdas itu sendiri. Pariwisata cerdas adalah sebuah transformasi yang sistematik dan intensif yang berbasis integrasi generasi baru Teknologi Informasi dan Komunikasi (TIK) untuk tujuan memuaskan kebutuhan pribadi wisatawan, memperbaiki pengalaman dan kepuasan wisatawan dalam berwisata, sehingga dapat mewujudkan keefektifan pengoptimalan sumberdaya pariwisata dan sumberdaya sosial [Zhang, 2012].

Sistem pariwisata cerdas ditinjau dari fasilitas dan sistem pelayanan meliputi elemen-elemen sebagai berikut [BIS, 2016, Bouskela et.al, 2016, Zeai dan Zeai, 2013, Panisiuk, 2007, Page, 2011, PP RI No. 50 Tahun 2011, dan Peneliti, 2017]:

1. Pelaku wisata

Pelaku wisata yang dimaksud adalah individu ataupun organisasi yang bergerak di bidang pariwisata yang dapat berupa institusi atau lembaga pemerintah, kelompok sadar wisata, akademisi di bidang wisata dan swasta dibidang pariwisata. Variabel pelaku wisata pada konteks pariwisata cerdas lebih menekankan adanya integrasi antara pelaku wisata dan didukung oleh TIK seperti software komputer yang digunakan yaitu untuk memudahkan dalam kegiatan koordinasi.

2. Atraksi

Atraksi merupakan sesuatu yang menarik dan menjadi tujuan wisatawan seperti objek wisata baik objek wisata dan event, namun event tidak termasuk karena terdapat kesulitan dalam mengukur event yang pengunjung wisatanya hanya ada saat berlangsung event serta lokasi event berubah setiap tahunnya. Fasilitas dan sistem pelayanan pada atraksi dilihat dari ketersediaan TIK seperti software komputer dan RFID serta kualitas pelayanan yang baik dalam atraksi.

3. Transportasi

Transportasi wisata merupakan sarana dan prasarana perjalanan yang menuju objek dan event wisata. Transportasi wisata ini didukung dengan pilihan moda transportasi umum yang merupakan fasilitas publik yang disediakan oleh pemerintah. Elemen transportasi ini, dikaji berdasarkan ketersediaan TIK dan kualitas pelayanan yang baik dalam transportasi.

4. Fasilitas penunjang wisata

Fasilitas penunjang wisata merupakan fasilitas yang mampu membantu wisatawan memenuhi kebutuhan pelayanan dasar maupun khusus saat berwisata. Fasilitas tersebut meliputi fasilitas keamanan, perbankan, akomodasi, rumah makan, perbelanjaan, kesehatan, sanitasi dan kebersihan, lahan parkir, ibadah dan pusat informasi pelayanan pariwisata. Elemen fasilitas penunjang wisata ini juga dikaji mengenai ketersediaan TIK dan kualitas pelayanan yang baik dalam fasilitas penunjang wisata.

\section{METODE PENELITIAN}

Pendekatan yang digunakan adalah pendekatan deduktif dengan metode kuantitaf melalui teknik analisis skoring. Teknik sampling yang digunakan adalah teknik accidental sampling pada pelaku wisata. Sesuai dengan sasaran, analisis yang digunakan terbagi menjadi dua tahapan, yaitu sebagai berikut.

1. Identifikasi Kesiapan Sub Variabel Pariwisata Cerdas

Analisis ini menggunakan teknik skoring untuk mengetahui kesiapan pada tiap sub variabel pariwisata cerdas. Kriteria penilaian kesiapan sub variabel tersebut seperti pada Tabel 1. 
Tabel 1. Analisis Kesiapan Sub Variabel Pariwisata Cerdas

\begin{tabular}{|c|c|c|c|c|}
\hline \multirow{2}{*}{ Sub Variabel } & \multirow{2}{*}{ Parameter } & \multicolumn{3}{|c|}{ Indikator } \\
\hline & & Siap (Skor 3) & Agalk Siap (Slkor 2) & Tidak Siap (Skor 1) \\
\hline \multicolumn{5}{|c|}{ Variabel pelaku wisata } \\
\hline $\begin{array}{l}\text { Ketersediaan dan } \\
\text { pemanfaatan TIK } \\
\text { untuk menunjang } \\
\text { integrasi pelaku } \\
\text { wisata }\end{array}$ & $\begin{array}{l}\text { Ketersediaan TIK untuk } \\
\text { menunjang integrasi } \\
\text { pelaku wisata }\end{array}$ & $\begin{array}{c}\text { Jika tersedia TIK untuk } \\
\text { menunjang integrasi } \\
\text { pelaku wisata memiliki } \\
\text { skor } 3,33-5\end{array}$ & $\begin{array}{c}\text { Jika tersedia TIK untuk } \\
\text { menunjang integrasi } \\
\text { pelaku wisata memiliki } \\
\text { skor } 1,67-3,32\end{array}$ & $\begin{array}{c}\text { Jika tersedia TIK untuk } \\
\text { menunjang integrasi } \\
\text { pelaku wisata memiliki } \\
\text { skor } 0-1,66\end{array}$ \\
\hline \multicolumn{5}{|c|}{ Variabel atraksi } \\
\hline $\begin{array}{l}\text { Ketersediaan dan } \\
\text { pemanfaatan TIK } \\
\text { untuk menunjang } \\
\text { atraksi }\end{array}$ & $\begin{array}{l}\text { Ketersediaan TIK yang } \\
\text { menunjang atraksi }\end{array}$ & $\begin{array}{l}\text { Jika tersedia TIK untuk } \\
\text { menunjang atraksi wisata } \\
\text { memiliki skor } 12,1-18\end{array}$ & $\begin{array}{l}\text { Jika tersedia TIK untuk } \\
\text { menunjang atraksi wisata } \\
\text { memiliki skor } 6,1-12\end{array}$ & $\begin{array}{c}\text { Jika tersedia TIK untuk } \\
\text { menunjang atraksi } \\
\text { wisata memiliki skor 0-6 }\end{array}$ \\
\hline $\begin{array}{l}\text { Kualitas } \\
\text { pelayanan yang } \\
\text { baik dalam } \\
\text { atraksi }\end{array}$ & $\begin{array}{l}\text { Keberagaman atraksi } \\
\text { wisata }\end{array}$ & $\begin{array}{l}\text { Memiliki keberagaman } \\
\text { atraksi wisata tinggi } \\
\left(\mathrm{H}^{\prime}>3\right)\end{array}$ & $\begin{array}{l}\text { Memiliki keberagaman } \\
\text { atraksi wisata sedang } \\
\qquad\left(1<\mathrm{H}^{\prime}<3\right)\end{array}$ & $\begin{array}{l}\text { Memiliki keberagaman } \\
\text { atraksi wisata rendah } \\
\left(\mathrm{H}^{\prime}<1\right)\end{array}$ \\
\hline \multicolumn{5}{|c|}{ Variabel transportasi } \\
\hline $\begin{array}{l}\text { Ketersediaan dan } \\
\text { pemanfaatan TIK } \\
\text { untuk menunjang } \\
\text { transportasi }\end{array}$ & $\begin{array}{l}\text { Ketersediaan TIK yang } \\
\text { menunjang } \\
\text { transportasi }\end{array}$ & $\begin{array}{l}\text { Jika tersedia software } \\
\text { permodelan transportasi, } \\
\text { pemetaan dan design } \\
\text { serta administrasi }\end{array}$ & $\begin{array}{c}\text { Jika tersedia software } \\
\text { administrasi serta salah } \\
\text { satu software antara } \\
\text { software permodelan } \\
\text { transportasi atau pemetaan } \\
\text { dan design. }\end{array}$ & $\begin{array}{l}\text { Jika hanya tersedia } \\
\text { software administrasi } \\
\text { atau tidak tersedia } \\
\text { software komputer } \\
\text { apapun. }\end{array}$ \\
\hline $\begin{array}{l}\text { Kualitas } \\
\text { pelayanan yang } \\
\text { baik dalam } \\
\text { transportasi }\end{array}$ & $\begin{array}{l}\text { Pelayanan transportasi } \\
\text { umum yang mampu } \\
\text { menjangkau semua } \\
\text { atraksi wisata }\end{array}$ & $\begin{array}{c}\text { Trayek transportasi } \\
\text { umum mampu } \\
\text { menjangkau } 66,7 \%-100 \% \\
\text { atraksi wisata }\end{array}$ & $\begin{array}{l}\text { Trayek transportasi umum } \\
\text { mampu menjangkau } \\
33,4 \%-66,6 \% \text { atraksi wisata }\end{array}$ & $\begin{array}{c}\text { Trayek transportasi } \\
\text { umum mampu } \\
\text { menjangkau 0\%-33,3\% } \\
\text { atraksi wisata }\end{array}$ \\
\hline \multicolumn{5}{|c|}{ Variabel fasilitas penunjang wisata } \\
\hline $\begin{array}{l}\text { Ketersediaan dan } \\
\text { pemanfaatan TIK } \\
\text { untuk menunjang } \\
\text { fasilitas } \\
\text { penunjang wisata }\end{array}$ & $\begin{array}{l}\text { Ketersediaan TIK yang } \\
\text { menunjang fasilitas } \\
\text { penunjang wisata }\end{array}$ & $\begin{array}{l}\text { Jika tersedia TIK untuk } \\
\text { menunjang fasilitas } \\
\text { penunjang wisata } \\
\text { memiliki skor } 6,1-9\end{array}$ & $\begin{array}{l}\text { Jika tersedia TIK untuk } \\
\text { menunjang fasilitas } \\
\text { penunjang wisata memiliki } \\
\text { skor } 3,1-6\end{array}$ & $\begin{array}{l}\text { Jika tersedia TIK untuk } \\
\text { menunjang fasilitas } \\
\text { penunjang wisata } \\
\text { memiliki skor 0-3 }\end{array}$ \\
\hline $\begin{array}{l}\text { Kualitas } \\
\text { pelayanan yang } \\
\text { baik dalam } \\
\text { fasilitas } \\
\text { penunjang wisata }\end{array}$ & $\begin{array}{l}\text { Ketersediaan fasilitas } \\
\text { penunjang wisata yang } \\
\text { dapat dijangkau dari } \\
\text { atraksi wisata dengan } \\
\text { berjalan kaki }\end{array}$ & $\begin{array}{c}\text { Persentase jumlah atraksi } \\
\text { wisata yang terjangkau } \\
\text { semua fasilitas penunjang } \\
\text { wisata dengan berjalan } \\
\text { kaki fasilitas adalah } \\
66,7 \%-100 \% \\
\end{array}$ & $\begin{array}{l}\text { Persentase jumlah atraksi } \\
\text { wisata yang yang } \\
\text { terjangkau semua fasilitas } \\
\text { penunjang wisata adalah } \\
33,4 \%-66,6 \%\end{array}$ & $\begin{array}{c}\text { Persentase jumlah } \\
\text { atraksi wisata yang yang } \\
\text { terjangkau semua } \\
\text { fasilitas penunjang } \\
\text { wisata adalah adalah } \\
0 \%-33,3 \%\end{array}$ \\
\hline
\end{tabular}

Sumber: Peneliti, 2017

2. Analisis Kesiapan Variabel Pariwisata Cerdas

Analisis ini merupakan analisis lanjutan yang menggunakan teknik skoring dengan cara mengakumulasikan skor kemudian dinilai hasil kesiapan tiap variabel seusai langkah-langkah berikut:

1) Menjumlahkan skor sub variabel dalam satu variabel

2) Menentukan rentang kelas interval dengan rumus interval untuk kriteria skor kesiapan setiap variabel

3) Menilai kesiapan tiap

variabelnya

Rumus interval yang digunakan yaitu

$$
\text { Interval }=\frac{\text { Nilai maksimal-Nilai Minimal }}{\text { Jumlah Kelas }}=\mathrm{y}
$$

Kategori tingkat kesiapan variabel pariwisata cerdas adalah sebagai berikut: 
Tabel 2. Analisis Kesiapan Variabel Pariwisata Cerdas

\begin{tabular}{|c|c|c|c|c|c|c|}
\hline Variabel & $\begin{array}{c}\text { Skor } \\
\text { maksimal }\end{array}$ & $\begin{array}{c}\text { Skor } \\
\text { minimal }\end{array}$ & $\begin{array}{c}\text { Hasil } \\
\text { interval }\end{array}$ & \multicolumn{3}{|c|}{ Indikator } \\
\cline { 5 - 7 } $\begin{array}{c}\text { Pelaku } \\
\text { wisata }\end{array}$ & 3 & 1 & 0,66 & $\begin{array}{c}\text { Siap (Skor 3) } \\
\text { variabel pelaku wisata } \\
\text { adalah 2.33-3 }\end{array}$ & $\begin{array}{c}\text { Agak Siap (Skor 2) } \\
\text { Jika hasil skoring } \\
\text { variabel pelaku wisata } \\
\text { adalah 1,67-2.32 }\end{array}$ & $\begin{array}{c}\text { Jika hasil skoring } \\
\text { variabel pelaku wisata } \\
\text { adalah l-1,66 }\end{array}$ \\
\hline Atraksi & 6 & 1 & 1,66 & $\begin{array}{c}\text { Jika hasil skoring } \\
\text { variabel atraksi } \\
\text { adalah 4,33-6 }\end{array}$ & $\begin{array}{c}\text { Jika hasil skoring } \\
\text { variabel atraksi } \\
\text { adalah 2.67-4,32 }\end{array}$ & $\begin{array}{c}\text { Jika hasil skoring } \\
\text { variabel atraksi } \\
\text { adalah l-2,66 }\end{array}$ \\
\hline Transportasi & 6 & 1 & 1,66 & $\begin{array}{c}\text { Jika hasil skoring } \\
\text { variabel transportasi } \\
\text { adalah 4,33-6 }\end{array}$ & $\begin{array}{c}\text { Jika hasil skoring } \\
\text { variabel transportasi } \\
\text { adalah 2.67-4,32 }\end{array}$ & $\begin{array}{c}\text { Jika hasil skoring } \\
\text { variabel transportasi } \\
\text { adalah } 1-2,66\end{array}$ \\
\hline $\begin{array}{c}\text { Fasilitas } \\
\text { Penunjang } \\
\text { Wisata }\end{array}$ & 6 & 1 & 1,66 & $\begin{array}{c}\text { Jika hasil skoring } \\
\text { variabel fasilitas } \\
\text { penunjang wisata } \\
\text { adalah 4,33-6 }\end{array}$ & $\begin{array}{c}\text { Jika hasil skoring } \\
\text { variabel fasilitas } \\
\text { penunjang wisata } \\
\text { adalah 2.67-4,32 }\end{array}$ & $\begin{array}{c}\text { Jika hasil skoring } \\
\text { variabel fasilitas } \\
\text { penunjang wisata } \\
\text { adalah 1-2,66 }\end{array}$ \\
\hline
\end{tabular}

Sumber: Peneliti, 2017

3. Analisis Kesiapan Pariwisata

Cerdas di Kota Surakarta

Analisis ini dilakukan melalui perhitungan skor kesiapan tiap variabel (hasil dari analisis skoring kesiapan variabel pariwisata cerdas) dengan bobot tiap variabel. Hasil perkalian tersebut kemudian diakumulasi. Ketentuan kategori tingkat kesiapan pariwisata cerdas digunakan rumus interval sebagai berikut:

$$
\begin{aligned}
\text { Interval } & =\frac{\text { Nilai maksimal-Nilai Minimal }}{\text { Jumlah Kelas }} \\
& =\frac{12-3}{3}=3
\end{aligned}
$$

Berdasarkan hasil interval yang diperoleh, dilakukan perumusan kategori tingkat kesiapan pariwisata cerdas Kota Surakarta adalah sebagai berikut:

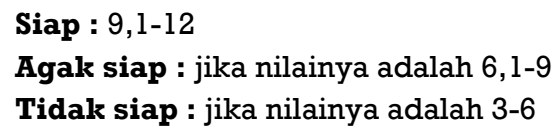

\section{HASIL DAN PEMBAHASAAN}

Penjabaran hasil analisis dan pembahasannya sesuai sasaran yaitu sebagai berikut:

1. Identifikasi kesiapan sub komponen pariwisata cerdas

a) Kesiapan Komponen Pelaku Wisata

- Ketersediaan TIK untuk Menunjang Integrasi Pelaku Wisata

Pengintegrasian pelaku wisata akan optimal jika ditunjang oleh ketersediaan dan pemanfaatan teknologi informasi dan komunikasi. Pada ketersediaan TIK ini dilihat dari ketersediaan software komputer pada saat koordinasi pariwisata. Untuk lebih detailnya dapat dilihat melalui Tabel 3 .

\begin{tabular}{|c|c|c|c|c|}
\hline Responden & $\begin{array}{l}\text { Tersedia/tidak } \\
\text { tersedia }\end{array}$ & $\begin{array}{c}\text { Bentuk software komputer yang } \\
\text { sering digunakan }\end{array}$ & Skor & $\begin{array}{l}\text { Rata- } \\
\text { rata } \\
\text { skor }\end{array}$ \\
\hline Pemerintah (Disbudpar) & Tersedia & $\begin{array}{l}\text { Ms. Word, Ms. Excel, Ms. Power } \\
\text { Point, Adobe Reader }\end{array}$ & 1 & 1 \\
\hline Pemerintah (Dishub) & Tersedia & $\begin{array}{l}\text { Ms. Word, Ms. Excel, Ms. Power } \\
\text { Point, Notepad, Adobe Reader }\end{array}$ & 1 & 1 \\
\hline Pemerintah (Diskominfo.S.P) & Tersedia & $\begin{array}{l}\text { Ms. Word, Ms. Excel, Ms. Power } \\
\text { Point, Notepad, Adobe Reader }\end{array}$ & 1 & 1 \\
\hline Pokdarwis & Tersedia & $\begin{array}{l}\text { Ms. Word, Ms. Excel, Ms. Power } \\
\text { Point }\end{array}$ & 1 & 1 \\
\hline $\begin{array}{l}\text { Taman Satwa Taru } \\
\text { Jurug }\end{array}$ & Tersedia & $\begin{array}{l}\text { Ms. Word, Ms. Excel, Ms. Power } \\
\text { Point, Adobe Reader }\end{array}$ & 1 & 0,88 \\
\hline
\end{tabular}

Tabel 3. Ketersediaan TIK untuk Menunjang Integrasi Pelaku Wisata 


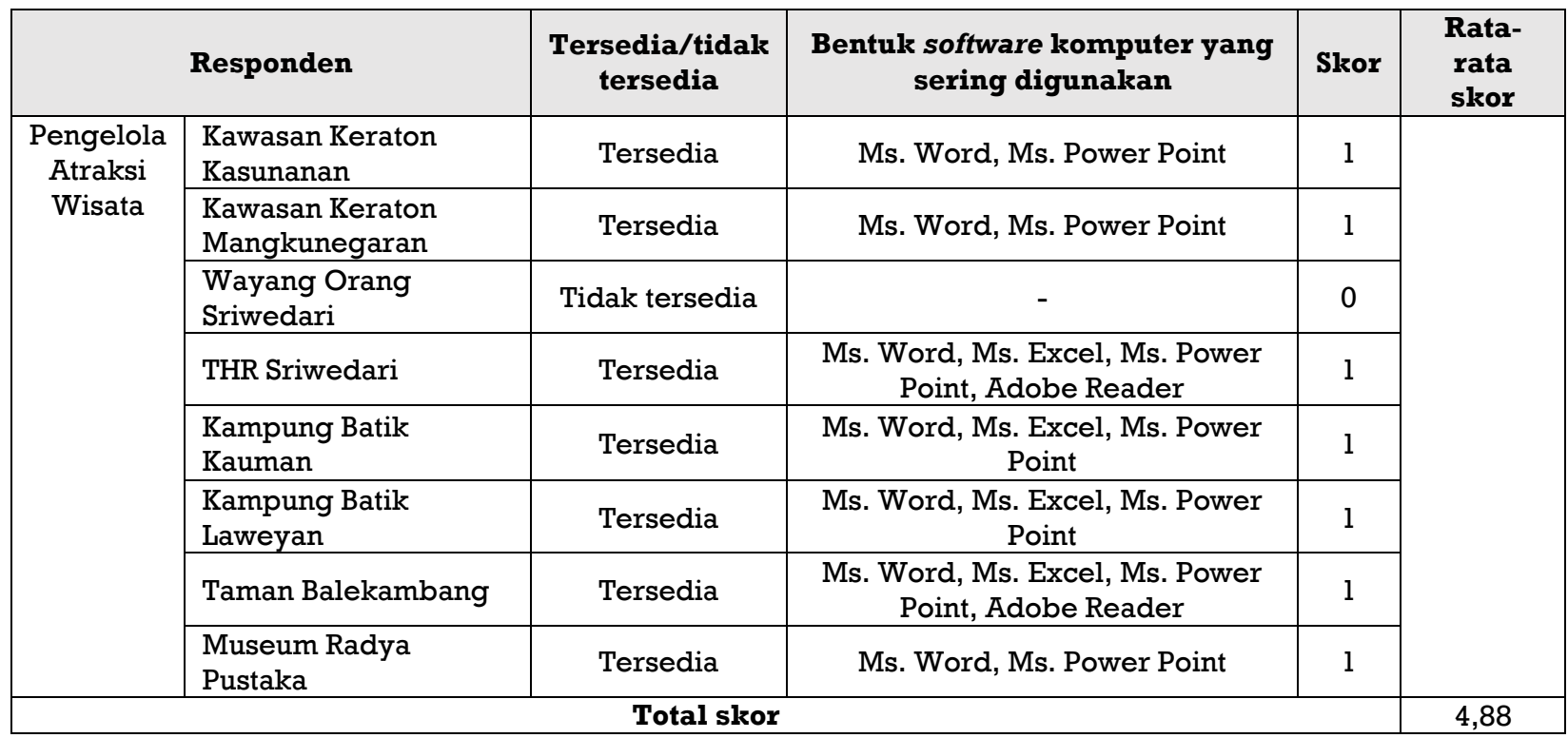

Sumber: Peneliti, 2017

Hasil analisis kesiapan ketersediaan TIK dalam menunjang integrasi pelaku wisata termasuk dalam siap. TIK yang berupa software komputer untuk menunjang saat koordinasi sudah tersedia dengan baik di Kota Surakarta, meskipun pada atraksi wisata Wayang Orang Sriwedari tidak tersedia software komputer sama sekali untuk integrasi pengelolaan wisatanya. Tidak tersedianya software komputer ini mengakibatkan kegiatan integrasi pelaku wisata tidak dapat memanfaatkan teknologi komputer yang mampu mengefektifkan kinerja. Oleh karena itu, Pemerintah Kota Surakarta diharapkan mampu mewujudkan terciptanya pengelolaan pariwisata yang terintegrasi dengan meningkatkan intensitas koordinasi antar pelaku wisatanya yang didukung dengan ketersediaan dan pemanfaatan TIK maupun IoT sehingga dapat berjalan dengan efektif dan efisien. Kesadaran antar pelaku wisata sebagai penggerak dalam menjalankan sistem kepariwisataan kota juga perlu ditingkatkan, karena tonggak terciptakan pariwisata yang maju dan cerdas adalah pelaku wisata.

b) Kesiapan Komponen Atraksi

- Ketersediaan TIK untuk Menunjang Atraksi

Ketersediaan TIK tersebut dilihat dari (1) ketersediaan software komputer untuk pengolahan data dan (2) ketersediaan smart card untuk tiket masuk yang menggunakan pembaca Radio Frequency Identify (RFID) maupun barcode/QR code scanner yang dinilai pada setiap atraksi wisata dengan observasi. Untuk lebih detailnya dapat dilihat melalui Tabel 5.

Tabel 4 Skor Ketersediaan TIK untuk Menunjang Atraksi Wisata

\begin{tabular}{|l|c|c|c|c|c|c|}
\hline \multirow{2}{*}{ Objek wisata } & \multicolumn{2}{|c|}{ Ketersediaan software komputer } & \multicolumn{3}{c|}{ Ketersediaan smart card } \\
\cline { 2 - 7 } & $\begin{array}{c}\text { Tersedia/ } \\
\text { Tidak tersedia }\end{array}$ & Bentuk & Skor & $\begin{array}{c}\text { Tersedia/ } \\
\text { Tidak tersedia }\end{array}$ & Bentuk & Skor \\
\hline $\begin{array}{l}\text { Taman Satwa } \\
\text { Taru Jurug }\end{array}$ & Tersedia & $\begin{array}{c}\text { Ms. Word, Ms. Excel, Ms. } \\
\text { Power Point, Adobe Reader }\end{array}$ & 1 & Tidak tersedia & - & 0 \\
\hline $\begin{array}{l}\text { Kawasan Keraton } \\
\text { Kasunanan }\end{array}$ & Tidak tersedia & - & 0 & Tidak tersedia & - & 0 \\
\hline $\begin{array}{l}\text { Kawasan Keraton } \\
\text { Mangkunegaran }\end{array}$ & Tidak tersedia & - & 0 & Tidak tersedia & - & 0 \\
\hline
\end{tabular}




\begin{tabular}{|l|c|c|c|c|c|c|}
\hline \multirow{2}{*}{ Objek wisata } & \multicolumn{2}{|c|}{ Ketersediaan software komputer } & \multicolumn{2}{c|}{ Ketersediaan smart card } \\
\cline { 2 - 6 } & $\begin{array}{c}\text { Tersedia/ } \\
\text { Tidak tersedia }\end{array}$ & Bentuk & Skor & $\begin{array}{c}\text { Tersedia/ } \\
\text { Tidak tersedia }\end{array}$ & Bentuk & Skor \\
\hline $\begin{array}{l}\text { Wayang Orang } \\
\text { Sriwedari }\end{array}$ & Tidak tersedia & - & Tidak tersedia & - & 0 \\
\hline THR Sriwedari & Tersedia & $\begin{array}{c}\text { Ms. Word, Ms. Excel, Ms. } \\
\text { Power Point }\end{array}$ & 1 & Tidak tersedia & - & 0 \\
\hline $\begin{array}{l}\text { Kampung Batik } \\
\text { Kauman }\end{array}$ & Tersedia & $\begin{array}{c}\text { Ms. Word, Ms. Excel, Ms. } \\
\text { Power Point }\end{array}$ & 1 & Tidak tersedia & - & 0 \\
\hline $\begin{array}{l}\text { Kampung Batik } \\
\text { Laweyan }\end{array}$ & Tersedia & $\begin{array}{c}\text { Ms. Word, Ms. Excel, Ms. } \\
\text { Power Point }\end{array}$ & 1 & Tidak tersedia & - & 0 \\
\hline $\begin{array}{l}\text { Taman } \\
\text { Balekambang }\end{array}$ & Tersedia & $\begin{array}{c}\text { Ms. Word, Ms. Excel, Ms. } \\
\text { Power Point }\end{array}$ & 1 & Tidak tersedia & - & 0 \\
\hline $\begin{array}{l}\text { Museum Radya } \\
\text { Pustaka }\end{array}$ & Tersedia & $\begin{array}{c}\text { Ms. Word, Ms. Excel, Ms. } \\
\text { Power Point }\end{array}$ & 1 & Tidak tersedia & - & 0 \\
\hline \multicolumn{2}{|c|}{ Sub total skor } & $\mathbf{7}$ & Sub total skor & $\mathbf{0}$ \\
\hline
\end{tabular}

Sumber: Peneliti, 2017

Total skor menunjukkan nilai 7 sehingga kesiapan ketersediaan TIK untuk menunjang atraksi termasuk pada kategori agak siap. Pada ketersediaan TIK dalam menunjang atraksi masih agak siap dikarenakan belum adanya objek wisata yang menyediakan smart card maupun pembaca RFID atau tiket kertas dengan barcode/QR code scanner. Serta belum tersedianya software komputer yang belum ada pada objek wisata Wayang Orang Sriwedari. Konsep kota cerdas ini merepresentasikan sebuah model pengembangan kota secara konseptual berdasarkan pemanfaatan manusia, komunitas dan teknologi untuk peningkatan pembangunan dan kesejahteraan di aglomerasi perkotaan [Angeladou, 2014], oleh karena itu meskipun objek wisata yang dominan di Kota Surakarta adalah wisata budaya yang identik dengan budaya tradisional namun seharusnya perkembangan layanan pariwisata mampu menyesuaikan dengan konsep kota cerdas yang ditunjang TIK sebagai wujud untuk peningkatan pembangunan dan kesejahteraan kota.

- Kualitas Pelayanan yang Baik dalam Atraksi

Kualitas pelayanan yang baik dalam objek wisata dapat diukur dengan menilai tingkat keberagaman jenis wisatanya melalui perhitungan indeks Shannon. Lebih detailnya dapat dilihat pada Tabel 7 dan Tabel 8.

Tabel 5. Data Jenis dan Jumlah Objek Wisata di Kota Surakarta

\begin{tabular}{|c|c|c|}
\hline $\begin{array}{c}\text { Jenis Objek } \\
\text { Wisata }\end{array}$ & Objek wisata & Jumlah \\
\hline Wisata Buatan & $\begin{array}{c}\text { Taman Satwa Taru Jurug, THR Sriwedari, Museum Radya Pustaka, } \\
\text { Taman Balekambang }\end{array}$ & 4 \\
\hline Wisata Belanja & Kampung Batik Kauman, Kampung Batik Laweyan & 2 \\
\hline Wisata Budaya & $\begin{array}{c}\text { Kawasan Keraton Kasunanan, Kawasan Keraton Mangkunegaran, } \\
\text { Wayang Orang Sriwedari }\end{array}$ & 3 \\
\hline \multicolumn{2}{|c|}{ Total } & 9 \\
\hline
\end{tabular}

Sumber: RIPKD Kota Surakarta 2016-2026, Analisis Penulis, 2017 
Tabel 6. Perhitungan Indeks Shannon Keberagaman Atraksi Wisata di Kota Surakarta

\begin{tabular}{|c|c|c|c|c|}
\hline Jenis Objek Wisata & Jumlah & $\mathbf{P i}=\sum \boldsymbol{n i} / \mathbf{N}$ & $\ln \mathbf{~ p i}$ & $\mathbf{H}$ \\
\hline Wisata Buatan & 4 & 0.44 & 1.386294361 & 0.616130827 \\
\hline Wisata Belanja & 2 & 0.22 & 0.693147181 & 0.154032707 \\
\hline Wisata Budaya & 3 & 0.33 & 1.098612289 & 0.366204096 \\
\hline \multicolumn{3}{|c|}{ Total objek wisata 9 } & H $^{\prime}=1.1363676$ \\
\hline
\end{tabular}

Sumber: Analisis Penulis, 2017

Hasil analisis sub komponen kualitas pelayanan yang baik dalam atraksi yaitu termasuk dalam kategori agak siap. Dari segi kualitas pelayanan objek wisata yang ditinjau dari keberagaman objek wisata masih pada tingkat sedang, karena kurangnya jenis wisata belanja. Kurangnya keberagaman jenis objek wisata, mengindikasikan belum mampunya sistem pariwisata Kota Surakarta untuk menyediakan beragam pilihan jenis objek wisata yang dapat dinikmati oleh pengunjung wisata.

c) Kesiapan Komponen Transportasi

- Ketersediaan TIK untuk Menunjang Transportasi

Adanya TIK untuk menunjang transportasi terutama transportasi umum yaitu dengan bentuk software komputer untuk pengolahan data transportasi. Penilaian dilakukan dengan observasi pada Dishub sebagai pengelola transportasi umum. Hal ini menunjukkan bahwa kesiapan ketersediaan TIK dalam menunjang transportasi tersebut termasuk dalam kategori siap. Ketersediaan TIK yang dimaksud adalah ketersediaan software komputer pada Dishub untuk mengelola transportasi umum. Hal ini terlihat dengan adanya kelengkapan jenis software komputer yang tersedia untuk menunjang pengolahan data dan pelayanan transportasi. Dinas Perhubungan (Dishub) sebagai pengelola transportasi umum dapat memanfaatkan TIK tersebut dan memungkinkan keefektifan kinerja pengelolaan transportasi.

Tabel 7. Ketersediaan TIK untuk Menunjang Transportasi

\begin{tabular}{|c|c|c|c|}
\hline $\begin{array}{c}\text { Objek } \\
\text { observasi }\end{array}$ & $\begin{array}{c}\text { Tersedia/tidak } \\
\text { tersedia }\end{array}$ & Jenis software komputer & $\begin{array}{c}\text { Bentuk software komputer yang } \\
\text { sering duigunakan }\end{array}$ \\
\hline $\begin{array}{c}\text { Pemerintah } \\
\text { (Dishub) }\end{array}$ & Tersedia & Permodelan transportasi & EMME-3 \\
\cline { 3 - 4 } & & Pemetaan dan design & $\begin{array}{c}\text { Arc.GIS, Corel Draw, Adobe } \\
\text { Photoshop, Auto CAD, Google Sketchup }\end{array}$ \\
\cline { 3 - 4 } & & Administrasi & $\begin{array}{c}\text { Ms. Word, Ms. Excel, Ms. Power Point, } \\
\text { Adobe Reader }\end{array}$ \\
\hline
\end{tabular}

Sumber: Peneliti, 2016

- Kualitas Pelayanan yang Baik dalam Transportasi

Penilaian kualitas pelayanan yang baik dalam transportasi ini dilakukan menggunakan indikator keterjangkauan objek wisata terhadap trayek transportasi umum , yakni radius 400 meter yang mampu ditempuh secara berjalan kaki [Peraturan Menteri Pekerjaan Umum tentang Pedoman Perencanaan, Penyediaan dan Pemanfaatan Prasarana dan Sarana Jaringan Pejalan Kaki di Kawasan Perkotaan, 2014]. 
Tabel 8.Indikator Kualitas Pelayanan yang Baik dalam Transportasi

\begin{tabular}{|c|c|c|}
\hline Objek wisata & Keterjangkauan dengan transportasi umum & $\begin{array}{c}\text { Nilai } \\
\text { persentase }\end{array}$ \\
\hline $\begin{array}{l}\text { Taman Satwa Taru } \\
\text { Jurug }\end{array}$ & $\begin{array}{l}\text { Terjangkau trayek BST Koridor 1, BST Koridor 2, BST Koridor 3, dan } \\
\text { Feeder BST Koridor } 3\end{array}$ & $100 \%$ \\
\hline $\begin{array}{l}\text { Kawasan Keraton } \\
\text { Kasunanan }\end{array}$ & $\begin{array}{l}\text { Terjangkau trayek BST Koridor 1, BST Koridor 3, Feeder BST Koridor 2, } \\
\text { Feeder BST Koridor 3, Feeder BST Koridor 4, Feeder BST Koridor 6, } \\
\text { Feeder BST Koridor 7, dan Feeder BST Koridor 8. }\end{array}$ & $100 \%$ \\
\hline $\begin{array}{l}\text { Kawasan Keraton } \\
\text { Mangkunegaran }\end{array}$ & $\begin{array}{l}\text { Terjangkau trayek BST Koridor 1, Feeder BST Koridor 2, Feeder BST } \\
\text { Koridor 1, Feeder BST Koridor 5, dan Feeder BST Koridor } 6 .\end{array}$ & $100 \%$ \\
\hline $\begin{array}{l}\text { Wayang Orang } \\
\text { Sriwedari }\end{array}$ & $\begin{array}{l}\text { Terjangkau trayek BST Koridor 1, BST Koridor 3, Feeder BST Koridor 4, } \\
\text { Feeder BST Koridor 6, dan Feeder BST Koridor } 7 \text {. }\end{array}$ & $100 \%$ \\
\hline THR Sriwedari & $\begin{array}{l}\text { Terjangkau trayek BST Koridor 1, BST Koridor 3, Feeder BST Koridor 4, } \\
\text { Feeder BST Koridor 6, dan Feeder BST Koridor 7. }\end{array}$ & $100 \%$ \\
\hline $\begin{array}{l}\text { Kampung Batik } \\
\text { Kauman }\end{array}$ & $\begin{array}{l}\text { Terjangkau trayek BST Koridor 1, BST Koridor 3, Feeder BST Koridor } 2 \text {, } \\
\text { Feeder BST Koridor 3, Feeder BST Koridor 4, Feeder BST Koridor 6, } \\
\text { Feeder BST Koridor 7, dan Feeder BST Koridor } 8 .\end{array}$ & $100 \%$ \\
\hline $\begin{array}{l}\text { Kampung Batik } \\
\text { Laweyan }\end{array}$ & $\begin{array}{l}\text { Terjangkau trayek BST Koridor 3, Feeder BST Koridor 5, dan Feeder } \\
\text { BST Koridor 7. }\end{array}$ & $100 \%$ \\
\hline Taman Balekambang & $\begin{array}{l}\text { Tidak terjangkau trayek transportasi umum baik BST maupun Feeder } \\
\text { BST }\end{array}$ & $0 \%$ \\
\hline $\begin{array}{l}\text { Museum Radya } \\
\text { Pustaka }\end{array}$ & $\begin{array}{l}\text { Terjangkau trayek BST Koridor 1, BST Koridor 3, Feeder BST Koridor 6, } \\
\text { dan Feeder BST Koridor } 7 .\end{array}$ & $100 \%$ \\
\hline \multicolumn{2}{|r|}{ Jumlah persentase } & $88,88 \%$ \\
\hline
\end{tabular}

Sumber: Peneliti, 2017

Hasil analisis kualitas pelayanan yang baik dalam transportasi mengindikasikan siap, meskipun salah satu objek wisata yaitu Taman Balekambang tidak terjangkau 400 meter dari trayek BST maupun Feeder $B S T$. Hal ini dikarenakan adanya rencana koridor BST lainnya yang belum diimplementasikan. Tidak terjangkaunya Taman Balekambang terhadap trayek transportasi umum dapat mempengaruhi dalam aksesibilitas objek wisata tersebut terutama untuk sebagian besar kalangan yang belum tentu mampu menggunakan transportasi pribadi.

d) Kesiapan Komponen Fasilitas Penunjang Wisata

- Ketersediaan TIK untuk Menunjang Fasilitas Penunjang Wisata

Ketersediaan TIK yang menunjang fasilitas penunjang wisata dinilai berdasarkan observasi pada fasilitas penunjang wisata yang paling dominan atau menonjol dalam penggunakan teknologinya. Lebih ditunjukkan pada Tabel berikut:

Tabel 9. Skor Ketersediaan TIK pada Fasilitas Penunjang Wisata

\begin{tabular}{|c|c|c|c|c|c|}
\hline $\begin{array}{l}\text { Fasilitas } \\
\text { Umum }\end{array}$ & $\begin{array}{c}\text { Bentuk } \\
\text { Pemanfaatan } \\
\text { TIK } \\
\end{array}$ & $\begin{array}{c}\text { Tersedia/ } \\
\text { tidak tersedia }\end{array}$ & Bentuk & Skor & $\begin{array}{l}\text { Rata } \\
\text {-rata } \\
\text { skor } \\
\end{array}$ \\
\hline $\begin{array}{l}\text { Fasilitas } \\
\text { keamanan }\end{array}$ & $\begin{array}{ll}\text { (1) software } \\
\text { komputer }\end{array}$ & Tersedia & $\begin{array}{c}\text { Ms. Office, software personnel data } \\
\text { information, software medical } \\
\text { repot,software Sistem Informasi } \\
\text { Aplikasi Pengembangan Perkara } \\
\text { (SIAPP), software inventaris } \\
\text { perkantoran } \\
\end{array}$ & 1 & 1 \\
\hline $\begin{array}{l}\text { Fasilitas } \\
\text { keuangan dan } \\
\text { perbankan }\end{array}$ & $\begin{array}{l}\text { (1) software } \\
\text { komputer }\end{array}$ & Tersedia & $\begin{array}{c}\text { Ms. Office, WAY4 Payment, } \\
\text { MasterCard internet Gateway } \\
\text { Service (MiGS), Easy Accounting } \\
\text { System (EAS) }\end{array}$ & 1 & 1 \\
\hline \multirow{2}{*}{$\begin{array}{l}\text { Fasilitas } \\
\text { akomodasi }\end{array}$} & $\begin{array}{l}\text { (1) software } \\
\text { komputer }\end{array}$ & Tersedia & Ms. Office, SIMSOFT HMS, SID Hotel & 1 & \multirow[t]{2}{*}{1} \\
\hline & (2) smart card & Tersedia & - & 1 & \\
\hline
\end{tabular}




\begin{tabular}{|c|c|c|c|c|c|}
\hline $\begin{array}{c}\text { Fasilitas } \\
\text { Umum }\end{array}$ & $\begin{array}{c}\text { Bentuk } \\
\text { Pemanfaatan } \\
\text { TIK }\end{array}$ & $\begin{array}{c}\text { Tersedia/ } \\
\text { tidak tersedia }\end{array}$ & Bentuk & Skor & $\begin{array}{l}\text { Rata } \\
\text {-rata } \\
\text { skor } \\
\end{array}$ \\
\hline $\begin{array}{l}\text { Fasilitas } \\
\text { rumah makan }\end{array}$ & $\begin{array}{l}\text { (1) } \begin{array}{l}\text { software } \\
\text { komputer }\end{array} \\
\end{array}$ & Tersedia & Ms. Office, Bee Accounting & 1 & 1 \\
\hline \multirow[b]{2}{*}{$\begin{array}{l}\text { Fasilitas } \\
\text { perbelanjaan }\end{array}$} & $\begin{array}{l}\text { (1) software } \\
\text { komputer }\end{array}$ & Tersedia & Ms. Office, K2_N2_Chasier & 1 & \multirow[b]{2}{*}{1} \\
\hline & $\begin{array}{l}\text { (2) barcode/ } \\
\text { QR code } \\
\text { scanner }\end{array}$ & Tersedia & - & 1 & \\
\hline $\begin{array}{l}\text { Fasilitas } \\
\text { kesehatan }\end{array}$ & $\begin{array}{l}\text { (1) software } \\
\text { komputer }\end{array}$ & Tersedia & Ms. Office, SIMRS & 1 & 1 \\
\hline $\begin{array}{l}\text { Fasilitas } \\
\text { sanitasi dan } \\
\text { kebersihan }\end{array}$ & $\begin{array}{l}\text { (1) } \begin{array}{l}\text { Sensor } \\
\text { robot }\end{array} \\
\text { robs }\end{array}$ & Tidak tersedia & - & 0 & 0 \\
\hline \multirow{2}{*}{$\begin{array}{l}\text { Fasilitas lahan } \\
\text { parkir }\end{array}$} & $\begin{array}{l}\text { (1) software } \\
\text { komputer }\end{array}$ & Tidak tersedia & Ms. Office, Parking System & 1 & \multirow[t]{2}{*}{1} \\
\hline & (2) smart card & Tidak tersedia & - & 1 & \\
\hline $\begin{array}{l}\text { Fasilitas } \\
\text { informasi dan } \\
\text { pelayanan } \\
\text { pariwisata }\end{array}$ & $\begin{array}{l}\text { (1) software } \\
\text { komputer }\end{array}$ & Tersedia & Ms. Office & 1 & 1 \\
\hline \multicolumn{5}{|c|}{ Total skor } & 8 \\
\hline
\end{tabular}

Sumber: Peneliti, 2016

Hasil analisis kesiapan ketersediaan TIK dalam menunjang fasilitas penunjang wisata termasuk dalam kategori siap. Hal ini karena sebagian besar objek wisata tersedia software komputer dan smart card, meskipun belum terdapat sensor robot yang mampu mendeteksi kesalahan membuang sampah pada fasilitas sanitasi dan kebersihan di Kota Surakarta. Hal tersebut mengindikasikan ketersediaan teknologi yang mampu menjadi alat pendukung pelayanan fasilitas kota belum menyeluruh.
- Kualitas Pelayanan yang Baik dalam Fasilitas Penunjang Wisata

Kualitas pelayanan yang baik dalam fasilitas penunjang wisata ini indikator penilaiannya yaitu ketersediaan fasilitas penunjang wisata yang dapat dijangkau dari atraksi wisata dengan berjalan kaki dengan radius 400 meter (Peraturan Menteri Pekerjaan Umum tentang Pedoman Perencanaan, Penyediaan dan Pemanfaatan Prasarana dan Sarana Jaringan Pejalan Kaki di Kawasan Perkotaan, 2014). Lebih detailnya dapat dilihat melalui Tabel 14. 
Tabel 10. Indikator Kualitas Pelayanan yang Baik dalam Fasilitas Penunjang Wisata

\begin{tabular}{|c|c|c|c|c|c|c|c|c|c|c|c|}
\hline \multirow[b]{2}{*}{ Objek wisata } & \multicolumn{10}{|c|}{ Jumlah jenis fasilitas penunjang wisata } & \multirow[b]{2}{*}{$\begin{array}{c}\text { Nilai } \\
\text { persentase } \\
\text { per jenis }\end{array}$} \\
\hline & 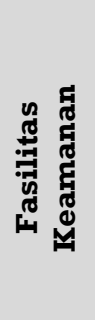 & 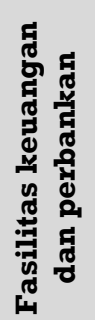 & 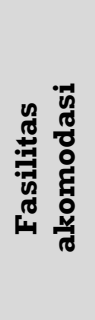 & 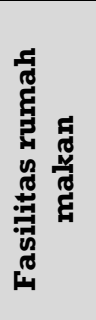 & 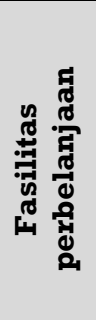 & 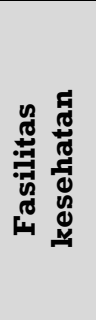 & 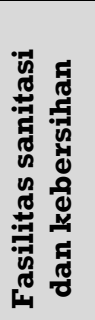 & 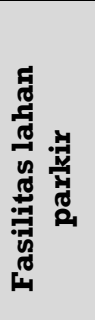 & 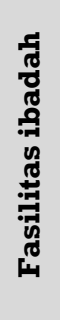 & 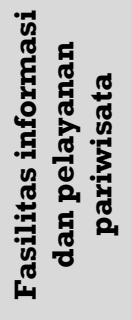 & \\
\hline $\begin{array}{l}\text { Taman Satwa Taru } \\
\text { Jurug }\end{array}$ & 0 & 1 & 0 & 29 & 72 & 0 & 2 & 2 & 2 & 1 & $0 \%$ \\
\hline $\begin{array}{l}\text { Kawasan Keraton } \\
\text { Kasunanan }\end{array}$ & 1 & 20 & 4 & 64 & 238 & 1 & 5 & 7 & 13 & 1 & $100 \%$ \\
\hline $\begin{array}{l}\text { Kawasan Keraton } \\
\text { Mangkunegaran }\end{array}$ & 1 & 10 & 10 & 29 & 144 & 1 & 1 & 1 & 2 & 2 & $100 \%$ \\
\hline $\begin{array}{l}\text { Wayang Orang } \\
\text { Sriwedari }\end{array}$ & 1 & 4 & 1 & 25 & 100 & 0 & 3 & 2 & 2 & 1 & $0 \%$ \\
\hline THR Sriwedari & 1 & 4 & 1 & 9 & 100 & 0 & 2 & 2 & 3 & 1 & $0 \%$ \\
\hline $\begin{array}{l}\text { Kampung Batik } \\
\text { Kauman }\end{array}$ & 4 & 27 & 10 & 66 & 314 & 1 & 4 & 6 & 10 & 1 & $100 \%$ \\
\hline $\begin{array}{l}\text { Kampung Batik } \\
\text { Laweyan }\end{array}$ & 0 & 7 & 5 & 72 & 155 & 4 & 1 & 2 & 13 & 0 & $0 \%$ \\
\hline $\begin{array}{l}\text { Taman } \\
\text { Balekambang }\end{array}$ & 1 & 1 & 3 & 77 & 92 & 2 & 4 & 5 & 4 & 1 & $100 \%$ \\
\hline $\begin{array}{l}\text { Museum Radya } \\
\text { Pustaka }\end{array}$ & 2 & 10 & 7 & 36 & 98 & 1 & 1 & 6 & 2 & 1 & $100 \%$ \\
\hline & & & Rat & ata p & sentas & & & & & & $55,55 \%$ \\
\hline
\end{tabular}

\section{Sumber: Peneliti, 2016}

Hasil analisis kualitas pelayanan yang baik dalam fasilitas penunjang wisata ditinjau dari keterjangkauan fasilitas penunjang wisata terhadap objek wisata termasuk dalam kategori agak siap. Pada aspek kualitas pelayanan yang baik lebih dari setengah objek wisata yang terjangkau semua jenis fasilitas penunjang wisata, yang menunjukkan pelayanan terhadap kebutuhan pribadi wisatawan untuk kegiatan pariwisata tidak terpenuhi dengan merata. Padahal idealnyakota harus mampu menyediakan semua fasilitas umum kota seperti layaknya fasilitas pribadi yang memenuhi kebutuhan masyarakat [BIS, 2013].

Tabel 11. Rekapitulasi Skor Kesiapan Karakteristik Fasilitas dan Sistem Pelayanan Pariwisata Cerdas

\begin{tabular}{|c|c|c|}
\hline Sub Komponen & Nilai Kesiapan & Skor \\
\hline \multicolumn{3}{|l|}{ Komponen pelaku wisata } \\
\hline Ketersediaan TIK untuk menunjang integrasi pelaku wisata & Siap & 3 \\
\hline \multicolumn{3}{|l|}{ Komponen atraksi } \\
\hline Ketersediaan TIK untuk menunjang atraksi & Agak siap & 2 \\
\hline Kualitas pelayanan yang baik dalam atraksi & Agak siap & 2 \\
\hline \multicolumn{3}{|l|}{ Komponen transportasi } \\
\hline Ketersediaan TIK untuk menunjang transportasi & Siap & 3 \\
\hline Kualitas pelayanan yang baik dalam transportasi & Siap & 3 \\
\hline \multicolumn{3}{|c|}{ Komponen fasilitas penunjang wisata } \\
\hline Ketersediaan TIK untuk menunjang fasilitas penunjang wisata & Siap & 3 \\
\hline Kualitas pelayanan yang baik dalam fasilitas penunjang wisata & Agak siap & 2 \\
\hline
\end{tabular}

Sumber: Peneliti, 2017 
Skor kesiapan sub komponen pariwisata cerdas seperti ditunjukkan pada Tabel 15., kemudian diakumulasi menjadi skor komponen. Berikut merupakan hasil nilai kesiapan tiap komponenya.

Tabel 12. Total Nilai Komponen Kesiapan Pariwisata Cerdas

\begin{tabular}{|c|c|c|c|c|c|c|}
\hline \multirow[b]{2}{*}{ Variabel } & \multirow[b]{2}{*}{$\begin{array}{l}\text { Total } \\
\text { skor }\end{array}$} & \multicolumn{3}{|c|}{ Indikator } & \multirow[b]{2}{*}{$\begin{array}{c}\text { Nilai } \\
\text { Kesiapan }\end{array}$} & \multirow[b]{2}{*}{$\begin{array}{c}\text { Skor } \\
\text { kesiapan }\end{array}$} \\
\hline & & Siap (Skor 3) & $\begin{array}{c}\text { Agak Siap } \\
\text { (Skor 2) }\end{array}$ & $\begin{array}{c}\text { Tidak Siap } \\
\text { (Skor 1) }\end{array}$ & & \\
\hline $\begin{array}{l}\text { Pelaku } \\
\text { wisata }\end{array}$ & 3 & $\begin{array}{c}\text { Jika hasil skoring } \\
\text { variabel pelaku } \\
\text { wisata adalah } \\
2.33-3\end{array}$ & $\begin{array}{c}\text { Jika hasil skoring } \\
\text { variabel pelaku } \\
\text { wisata adalah } \\
1,67-2.32\end{array}$ & $\begin{array}{c}\text { Jika hasil skoring } \\
\text { variabel pelaku } \\
\text { wisata adalah l- } \\
1,66\end{array}$ & Siap & 3 \\
\hline Atraksi & 4 & $\begin{array}{c}\text { Jika hasil skoring } \\
\text { variabel atraksi } \\
\text { adalah 4,33-6 }\end{array}$ & $\begin{array}{c}\text { Jika hasil skoring } \\
\text { variabel atraksi } \\
\text { adalah } 2.67-4,32\end{array}$ & $\begin{array}{c}\text { Jika hasil skoring } \\
\text { variabel atraksi } \\
\text { adalah } 1-2,66\end{array}$ & Agak siap & 2 \\
\hline Transportasi & 6 & $\begin{array}{c}\text { Jika hasil skoring } \\
\text { variabel } \\
\text { transportasi } \\
\text { adalah } 4,33-6\end{array}$ & $\begin{array}{c}\text { Jika hasil skoring } \\
\text { variabel } \\
\text { transportasi } \\
\text { adalah } 2.67-4,32\end{array}$ & $\begin{array}{c}\text { Jika hasil skoring } \\
\text { variabel } \\
\text { transportasi } \\
\text { adalah } 1-2,66\end{array}$ & Siap & 3 \\
\hline $\begin{array}{c}\text { Fasilitas } \\
\text { Penunjang } \\
\text { Wisata }\end{array}$ & 5 & $\begin{array}{c}\text { Jika hasil skoring } \\
\text { variabel fasilitas } \\
\text { penunjang wisata } \\
\text { adalah } 4,33-6\end{array}$ & $\begin{array}{l}\text { Jika hasil skoring } \\
\text { variabel fasilitas } \\
\text { penunjang wisata } \\
\text { adalah } 2.67-4,32\end{array}$ & $\begin{array}{c}\text { Jika hasil skoring } \\
\text { variabel fasilitas } \\
\text { penunjang wisata } \\
\text { adalah } 1-2,66\end{array}$ & Siap & 3 \\
\hline \multicolumn{6}{|c|}{ Total } & 11 \\
\hline
\end{tabular}

Sumber: Peneliti, 2017

\section{Analisis Kesiapan Pariwisata Cerdas} di Kota Surakarta

Analisis ini merupakan analisis terakhir yang mengakumulasikan seluruh skor kesiapan komponen pariwisata cerdas ditinjau dari fasilitas dan sistem palayanannya yang kemudian menghasilkan nilai kesiapan Kota Surakarta dalam mewujudkan pariwisata cerdas. Dengan total keseluruhan nilai komponen pariwisata cerdas yaitu 11 sehingga jika dianalisis dengan kriteria kesiapannya, maka Kota Surakarta dinyatakan siap ditinjau dari fasilitas dan sistem palayanannya dalam mewujudkan pariwisata cerdas.

Hasil penelitian ini menunjukkan bahwa komponen-komponen dalam pariwisata cerdas jika ditinjau dari fasilitas dan sistem pelayanan sebagian menunjukkan siap seperti pelaku wisata yang berdampak pada adanya keefektifan dan efesiensi kinerja pelaku wisata dalam mengelola komponen lain dalam sistem pariwisata. Namun komponen atraksi sebagai daya tarik utama pariwisata kota menunjukkan agak siap, hal ini berdampak pada belum mampunya atraksi berperan sebagai komponen utama pariwisata yang mampu menarik banyak pengunjung wisata, terkikisnya kebanggaan masyarakat dan sense of belongness objek wisata, menyebabkan juga layanan transportasi dan fasilitas penunjang wisata menjadi tidak termanfaatkan dengan baik karena minat pengunjung wisata yang sedikit.

Komponen transportasi dan fasilitas penunjang wisata yang siap, berperan dalam peningkatan kualitas pelayanan yang efektif dan efisien sebagai sarana dan prasarana untuk memenuhi kebutuhan pengunjung wisata baik untuk perjalanan serta kebutuhan lainnya. 


\section{KESIMPULAN}

1) Kesimpulan

Kota Surakarta termasuk siap untuk mewujudkan pariwisata cerdas ditinjau dari fasilitas dan sistem pelayannanya. Komponen yang siap tersebut meliputi ketersediaan dan pemanfaatan TIK dalam menunjang pelaku wisata, serta ketersediaan dan pemanfaatan TIK dalam menunjang transportasi dan kualitas pelayanan yang baik dalam transportasi. Namun beberapa aspek masih perlu di tingkatkan kualitas dan kuantitasnya karena masih menunjukkan kategori agak siap dan tidak siap, seperti pemanfaatan TIK dan kualitas pelayanan yang baik dalam fasilitas penunjang wisata. Terutama pada komponen atraksi wisata seperti ketersediaan dan pemanfaatan TIK untuk menunjang atraksi serta kualitas pelayanan yang baik dalam atraksi. Hasil tinjauan pada aspek fasilitas dan sistem pelayanan pada kesiapan komponen pariwisata cerdas, menunjukkan adanya kesiapan untuk komponen pelaku wisata, transportasi dan fasilitas penunjang wisata.

\section{2) Rekomendasi}

Rekomendasi yang dapat diajukan berdasarkan hasil artikel ini yaitu sebagai berikut:

1) Meningkatkan intensitas koordinasi antar pelaku wisatanya yang didukung dengan ketersediaan TIK yang mampu mengefektifkan kinerja sehingga mampu mewujudkan terciptanya pengelolaan pariwisata yang terintegrasi dengan baik.

2) Meningkatkan kesadaranbahwa atraksi wisata merupakan faktor utama penarik pengunjung yang menikmati wisata kota sehingga menjadi pacuan untuk meningkatkan kualitas pelayanan daya tarik wisata. Hal ini terutama dengan dukungan ketersediaan software komputer dan smart card yang maju sehingga kinerja menjadi efektif dan efisien. Kualitas pelayanan yang baik juga perlu ditingkatkan terutama keberagaman atraksi wisata sehingga pengunjung memiliki pilihan jenis objek wisata yang dapat dinikmati.

3) Meningkatkan aksesibilitas atraksi wisata dengan penambahan jalur trayek transportasi umum terutama menuju ke objek wisata Taman Balekambang

4) Meningkatkan ketersediaan semua jenis fasilitas penunjang wisata yang mampu memenuhi kebutuhan pelayanan untuk bagi pengunjung wisata. Ketersediaan software komputer, sensor robot, smart card dan barcode scanner juga perlu diprioritaskan pada fasilitas penunjang wisata, sehingga menambah kepuasan pengguna dan memberikan pengalaman tersendiri melalui pelayanan dengan teknologi canggih.

\section{REFERENSI}

Angelidou, M. 2014. Smart city policies: $A$ spatial approach. Jurnal. Cities 41: S3-S1l. http://dx.doi.org/10.1016/j.cities. 2014.06.007

BIS. 2013. Smart Cities: Background Paper. UK : Crown

Bussiness Dictionary. Readiness Definition.

http://www.businessdictionary.co m/definition /readiness.html. Diakses tanggal 19 Oktober 2016

Indosat Ooredo Business. 2015. Layanan M2M Indosat untuk Aplikasi E-Tax Dukung Perwujudan SmartCity di Kota Surakarta. https://indosatooredoo.com/id/b usiness/support/newsevent/news/m2m-indosatdukung-smart-city-kotasurakarta.Diakses tanggal 18 September 2016

Liu, $\mathrm{Pu}$ dan Liu, Yuan. 2016. Smart Tourism via Smart Phone. Proceeding of International Conference on Communications, Information Management and Network Security (CIMNS 2016) 
Piro, G., Cianci, I., Grieco, L.A., Boggia, G., Camarda, P. 2014. Information centric services in Smart Cities. The Journal of Systems and Software 88, 169- 188 (2014)

Rustanto. 2007. Pengembangan Usaha Rakyat. Graha Ilmu: Bandung

Sinambela. 2007. Reformasi Pelayanan Publik. Jakarta: Bumi Aksara

UNWTO. 2012. Tourism resilience committee stresses need for "Smart Tourism"[EB/OL].www.slideshare. com, Diakses tanggal 30 November 2016.

Zhang, L. 2012. Smart Tourism: The Coming era of Personalization and Intelligent Public Services. Tourism Tribune, 27(2), 3-5

Zhui, W., Zhang, L., Li, N. 2014. Challenges, Function Changing of Government and Enterprises in Chinese Smart Tourism. Information and Communication Technologies in Chinese Smart Tourism. Dublin: Spinger 